\title{
STATISTICAL ANALYSIS OF GROWTH CONDITIONS OF NEWLY ISOLATE BACILLUS SP. PRODUCING L-ASPARAGINASE
}

\author{
DZUN NORAINI JIMAT ${ }^{1 *}$, INTAN BAIZURA FIRDA MOHAMED ${ }^{1}$, AZLIN SUHAIDA AZMi ${ }^{1}$ AND \\ AZURA AMID ${ }^{2}$
}

${ }^{1}$ Department of Biotechnology Engineering, Kulliyyah of Engineering, International Islamic University Malaysia (IIUM), P.O. Box 10, 50728 Kuala Lumpur, Malaysia.

${ }^{2}$ International Institute for Halal Research and Training, International Islamic University. Malaysia (IIUM), P.O. Box 10, 50728 Kuala Lumpur, Malaysia.

*Corresponding author: jnoraini@iium.edu.my

(Received: $4^{\text {th }}$ February 2019; Accepted: $13^{\text {th }}$ June 2020; Published on-line: $4^{\text {th }}$ July 2020)

\begin{abstract}
The concentrations of nutrient elements together with several physical parameters were screened to find out the significant factors for the production of Lasparaginase from newly isolated strain, Bacillus sp. from Sg Klah, Hot Spring, Perak. Then, the significant factors were optimized for enhancing L-asparaginase production from the bacterium strain. Two statistical designs, Two Level Factorial Design and Face Centered Composite Design (FCCD), Design expert @version 8.0 were employed in screening and optimization of the process variables, respectively. The results for all experiment runs were analyzed by analysis of variance (ANOVA). Peptone (nitrogen source) concentration and temperature were found as significant factors, positively influenced the production of Lasparaginase. The two factors were then optimized to increase the desired enzyme production. The optimum peptone concentration and the temperature were found at $1.4 \mathrm{~g} / \mathrm{L}$ and $30^{\circ} \mathrm{C}$, respectively. The L-asparaginase production under optimized conditions increased from $0.15 \pm 0.023 \mathrm{U} / \mathrm{mL}$ to $0.19 \pm 0.03 \mathrm{U} / \mathrm{mL}$. The kinetic studies showed that the biomass production dropped after 24 hours while L-asparaginase activity is active and positively increased until the fermentation period ended.
\end{abstract}

ABSTRAK: Kepekatan unsur-unsur nutrien bersama-sama dengan beberapa parameter fizikal telah diteliti untuk mengetahui faktor-faktor penting untuk pengeluaran L-asparaginase dari spesis baru diasingkan, bacillus sp. dari kolam air panas tempatan. Kemudian, faktor penting dioptimumkan untuk meningkatkan pengeluaran L-asparaginase daripada bakteria tersebut. Two Level Factorial Design dan Face Centered Composite Design (FCCD), Design expert @ version 8.0 telah digunakan dalam penyaringan dan pengoptimuman pembolehubah proses dalam kajian ini. Keputusan untuk semua eksperimen dianalisis dengan analisis varians (ANOVA). Kepekatan dan suhu peptone (sumber nitrogen) didapati sebagai faktor penting, secara positif mempengaruhi pengeluaran L-asparaginase. Kedua-dua faktor ini dioptimumkan untuk meningkatkan pengeluaran enzim yang dikehendaki. Kepekatan peptone dan suhu optimum didapati masing-masing pada $1.4 \mathrm{~g} / \mathrm{L}$ dan $30^{\circ} \mathrm{C}$. Pengeluaran Lasparaginase di bawah keadaan yang dioptimumkan meningkat dari $0.15 \pm 0.023 \mathrm{U} / \mathrm{mL}$ kepada $0.19 \pm 0.03 \mathrm{U} / \mathrm{mL}$. Kajian kinetik menunjukkan bahawa pengeluaran biojisim menurun selepas 24 jam manakala aktiviti L-asparaginase aktif dan meningkat secara positif sehingga tempoh penapaian berakhir.

KEYWORDS: Bacillus sp., L-asparaginase activity, screening, optimization, peptone, temperature 


\section{INTRODUCTION}

L-asparaginase catalyzes the hydrolysis of L-asparagine into L-aspartic acid and ammonia. L-asparaginase is widely used in food industry as an acrylamide reducing agent especially in baked and fried food products [1] as when the temperature in processing food is getting higher, the acrylamide compound is formed [2]. This enzyme is also known as a microbial therapeutic approach for cancer treatment [3]. This enzyme helps in reducing the amount of L-asparagine present in patients' blood by hydrolyzing the amino acid to two end products in leukemic cells [4]. Tumor cell needs L-asparagine to build proteins. However, these cells cannot synthesize its own L-asparagine because of the absent or low expression of asparagine synthase in the cells. Therefore, the cells use exogenous L-asparagine that obtains from the human diet to meet its needs. This enzyme is also used as a diagnostics biosensor for monitoring asparagine levels in leukemia [4]. L-asparaginase serves to destroy all the L-asparagine that does not manage to get synthesized in a tumor cell or that comes from the other sources [5]. L-asparaginase is an important component for cancer therapy, but it still has some limitations for clinical utility due to its side effect, short half-life and low-level enzyme production [6]. The current microbial strains producing L-asparaginase that are used for therapeutic are from Escherichia coli and Erwinia sp. [7]. The therapeutic response of L-asparaginase from these bacteria strains usually occurs with the evidence of toxicity [8]. A native form of the enzyme has a short half-life [9]. The fast progress of clinical resistance (the failure of cancer to shrink after treatment) is the key problem of L-asparaginase usage in treating acute leukemia. A long term administration of L-asparaginase into patients may cause the production of the corresponding antibody in the tissues. This condition may result in anaphylactic shock or neutralization of the drug effect. It was found that different types of microbial strains exhibit different biochemical and kinetic properties of L-asparaginase [10]. Previous studies have discovered new strains that able to produce asparaginase such as Helicobacter pylori $[11,12]$, Serratia marcescens $[13,14]$ and basidiomycetes, Flammulina velutipes [15]. However, alternative L-asparaginase sources are a necessity to meet a great demand that is expected in the coming years. It is because microbes are preferable sources than animals and plants due to their fast and easily grow and low-cost of culture nutrient requirements [16]. Thus, this study aimed to screen the significant factors in enhancing L-asparaginase production by newly isolated Bacillus $s p$. obtained from our previous study [17]. The significant factors were then optimized to maximize enzyme production. The growth kinetic of the bacterial strain under optimum conditions was investigated. In this study, face-centered central composite design (FCCD) from Response Surface Methodology (RSM) using Design expert @version 8.0 was selected as through this approach optimum values could be discovered effectively within the designated range of the independent variable. Furthermore, a previous study reported that the effect of several process variables on the prediction of the optimum response yield could be observed as well [18].

\section{MATERIALS AND METHODS}

\subsection{Microorganisms}

A bacteria strain producing L-asparaginase from Bacillus $s p$. was used in the present study. The wild strain of Bacillus sp. was isolated previously from Sg. Klah, Hot Spring, Perak [17]. The pure bacterial strain was maintained in glycerol stock at $-20^{\circ} \mathrm{C}$ to preserve it. Then it was subcultured on nutrient agar before use. The culture plates were then stored at $4^{\circ} \mathrm{C}$ and subcultured every two weeks. 


\subsection{Identification of the isolate bacteria}

Molecular identification using 16S rRNA gene sequencing analysis was performed by 1 st BASE Molecular Biology Services. BLAST program was used to identify the gene sequence.

\subsection{Inoculum preparation}

A bacteria suspension was prepared from 24 hours old culture grown on modified M9 agar medium as described by Gulati and co-workers (1997) [19]. This modified M9 medium containing (per $1000 \mathrm{~mL}$ of distilled water): $\mathrm{Na}_{2} \mathrm{HPO}_{4} .2 \mathrm{H}_{2} \mathrm{O}, 6.0 \mathrm{~g} ; \mathrm{KH}_{2} \mathrm{PO}_{4}, 3.0 \mathrm{~g} ; \mathrm{NaCl}, 0.5$ $\mathrm{g}$; L-asparagine, $5.0 \mathrm{~g} ; 1 \mathrm{M} \mathrm{MgSO} 4.7 \mathrm{H}_{2} \mathrm{O}, 2.0 \mathrm{~mL} ; 0.1 \mathrm{M} \mathrm{CaCl}_{2} .2 \mathrm{H}_{2} \mathrm{O}, 1.0 \mathrm{~mL} ; 20 \%$ glucose stock, $10.0 \mathrm{~mL}$; agar $20.0 \mathrm{~g}$ at $\mathrm{pH}$ 7. A colony from the culture plates was suspended in $5 \mathrm{~mL}$ of sterile liquid M9 medium. It was grown overnight at $37^{\circ} \mathrm{C}$.

\subsection{Cultivation of newly isolates, Bacillus sp.}

Sterilized modified M9 media $(50 \mathrm{~mL})$ was inoculated with $2 \%\left(1.46 \times 10^{8} \mathrm{CFU} / \mathrm{mL}\right)$ of inoculums (Bacillus sp.) which placed in $250 \mathrm{~mL}$ Erlenmeyer flasks and incubated at $37^{\circ} \mathrm{C}$ at $150 \mathrm{rpm}$ for 48 hours. The uninoculated medium was used as a control. The same experiment was carried out in three times. L-asparaginase activity was determined by taking the culture broth sample after 48 hours of incubation time.

\subsection{L-asparaginase assay}

The collected sample cultures were analyzed as described in previous studies $[17,19]$. The bacteria cultures were harvested by centrifugation at $6,000 \mathrm{rpm}$ for $15 \mathrm{~min}$. A mixture of 0.1 $\mathrm{ml}$ sample of enzyme extract with $0.2 \mathrm{ml}$ of $0.05 \mathrm{M}$ Tris-HCL $(\mathrm{pH} 8.6), 1.7 \mathrm{ml}$ of $0.01 \mathrm{M} \mathrm{L}$ asparagine was incubated for $10 \mathrm{~min}$ at $37^{\circ} \mathrm{C} .5 \mathrm{ml}$ of $1.5 \mathrm{M}$ trichloroacetic acid (TCA) was added to the mixture to stop the reaction. This mixture was centrifuged at 10,000 rpm for clarification then $0.5 \mathrm{ml}$ of the supernatant was diluted to $7 \mathrm{ml}$ with distilled water and treated with $1 \mathrm{ml}$ of Nessler reagent and left for $10 \mathrm{~min}$. The absorbance of color changes was measured at $480 \mathrm{~nm}$. The optical density (OD) readings were then compared to the standard curve of ammonia. One unit (U) of L-asparaginase was defined as that amount of enzyme which liberating $1 \mu$ mole of ammonia per minute at $37^{\circ} \mathrm{C}$ under the assay conditions.

\subsection{Protein concentration}

Protein concentration was determined using reagent (Pierce ${ }^{\mathrm{TM}}$ 660nm Protein Assay Reagent) and compared to a standard curve of Bovine Serum Albumin (BSA) concentration as described by Bradford, (1976)[21].

\subsection{Screening of carbon and nitrogen concentrations and operating culture conditions by Two-Level Factorial Design}

Two-Level Factorial Designs, Design expert@version 8.0 was applied for screening of significant concentration of carbon and nitrogen sources. Based on the previous part of our study [17], it was found that sucrose and peptone positively enhanced the L-asparaginase activity from the used bacterial strain, Bacillus sp. The concentrations of the two nutrient components were screened together with the other culture operating conditions such as $\mathrm{pH}$, inoculum sizes, agitation speed, and temperature to determine the most significant parameters for L-asparaginase production by the strain. Sucrose and peptone were supplemented at certain 
concentrations into the production medium as reported in the previous study [22]. The design contains 32 experimental runs where the factors were taken at two levels (high and low values) as illustrated in Table 1.

Table 1: Controllable factors and their coded levels for screening the significant factors using Two-Level Factorial Design

\begin{tabular}{lccc}
\hline Factor & Code & \multicolumn{2}{c}{ Variable levels } \\
& & $-1($ Low $)$ & $+1($ High $)$ \\
\hline Carbon $(\mathrm{g} / \mathrm{l})$ & $\mathrm{A}$ & 1.50 & 3.00 \\
Nitrogen $(\mathrm{g} / \mathrm{l})$ & $\mathrm{B}$ & 1.50 & 3.00 \\
Temperature $\left({ }^{\circ} \mathrm{C}\right)$ & $\mathrm{C}$ & 37 & 60 \\
$\mathrm{pH}$ & $\mathrm{D}$ & 5 & 9 \\
Agitation speed $(\mathrm{rpm})$ & $\mathrm{E}$ & 150 & 250 \\
Inoculum sizes $(\%)$ & $\mathrm{F}$ & 2 & 3.5 \\
\hline
\end{tabular}

\subsection{Optimization of significant factors using Face Centered Composite Design (FCCD) from Response Surface Methodology (RSM)}

Face Centred Composite Design (FCCD) from Response Surface Methodology (RSM) using Design expert@version 8.0 was employed to optimize the response (enzyme activity)which was influenced by the independent variables such as medium components (carbon and nitrogen sources) and operating parameters $(\mathrm{pH}$, inoculum sizes and agitation speed). The significant factors were selected based on the results obtained in section 2.7. All results were analyzed by ANOVA and validated.

\subsection{RESULTS AND DISCUSSION}

The most potent isolate (I3) with high potential for L- asparaginase production was selected and identified using 16S rRNA gene sequence analysis for classification and to further confirm the subspecies level.

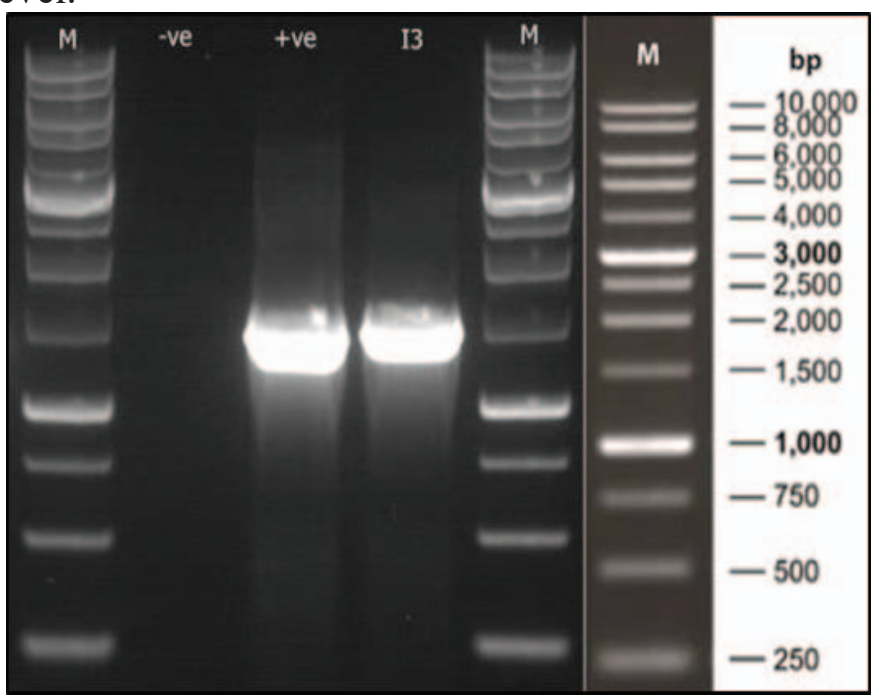

Fig. 1. PCR products for 16S rRNA gene sequence (M: DNA marker; -ve: PCR non template control (water); +ve: DNA extracted from E.coli ; I3: isolated strain) 
Based on Fig. 1, a single band of the DNA appeared between 1000 and 1500 bp sequence. The result revealed a single band of amplified DNA products of approximately 1373 base pairs was recorded. The complete sequence data of the $16 \mathrm{~S}$ ribosomal RNA gene were aligned and analyzed for finding the closest homologous microbes. The gene sequence was compared to nucleotide databases using the BLAST program.

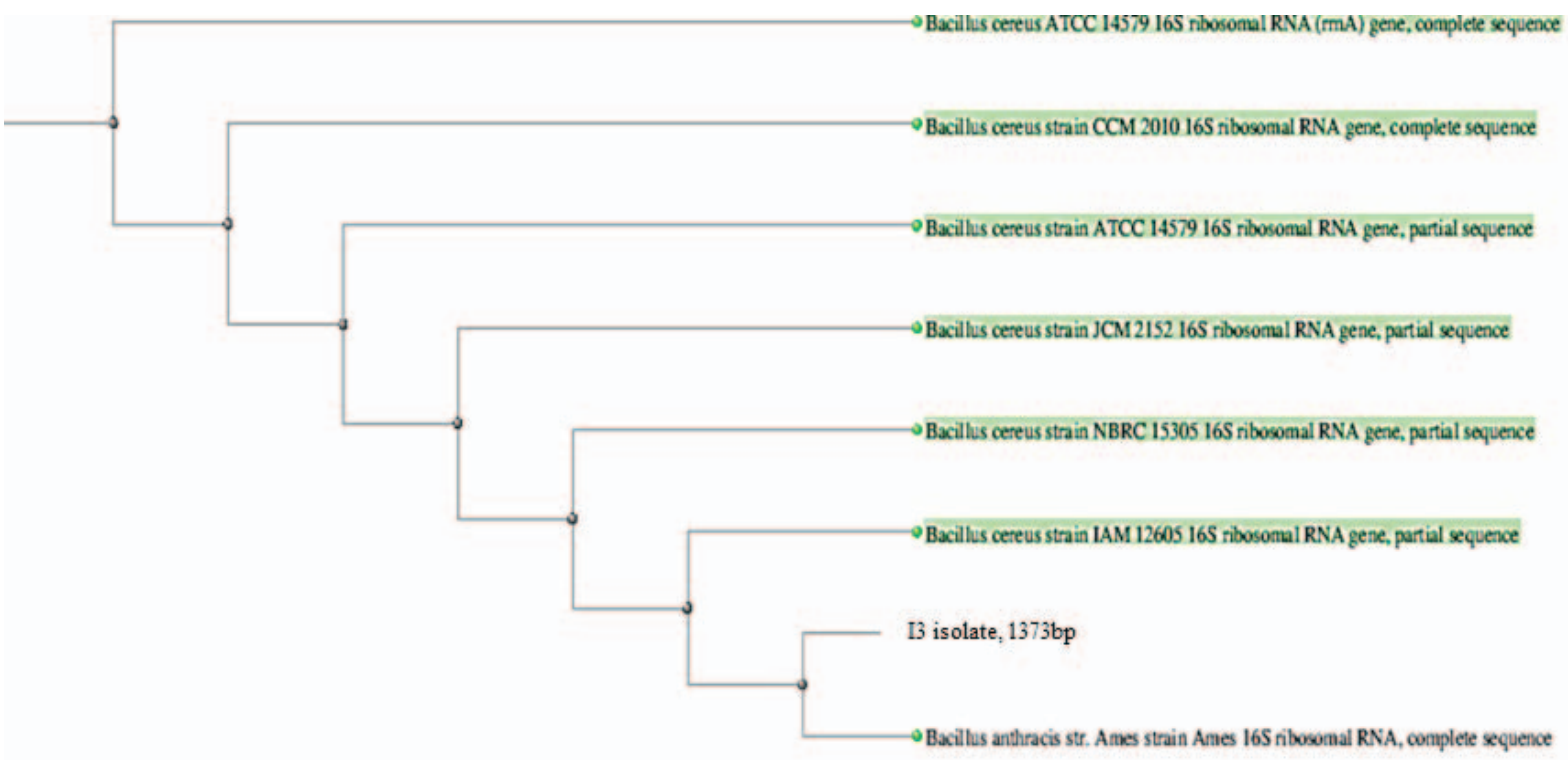

Fig. 2. A Phylogenetic tree of I3 strain. Neighbor-joining tree based on 16S rRNA gene sequences showing the positions of the selected strain.

A phylogenetic tree (Fig. 2) was constructed by taking the sequences obtained in the blast search. It was constructed to illustrate the evolutionary relationship between the unknown strains and the most closely related strains of species of the genus. As illustrated in Fig. 2, I3 strain was clustered into two major clades. The analysis of 16S rDNA sequences showed the sequences of the selected strain that very closely related to Bacillus sp. Therefore, based on Fig. 2, I3 isolate was identified as Bacillus anthracis. The sequence of the selected strain was most closely related to Bacillus anthracis strain Ames with a sequence similarity of $98 \%$.

Sucrose and peptone were found as the best nutrients to boost L-asparaginase activity based on our previous study [17]. The varied concentration of the two elements together with four operating parameters like temperature, agitation speed, $\mathrm{pH}$, and inoculum sizes were screened to investigate the significant factors influencing L-asparaginase activity from the Bacillus sp. strain. The experiment was designed under Two-Level Factorial Designs. The concentration of nutrients elements is vital to enhance bacterial growth as well as metabolites production during the fermentation process. 


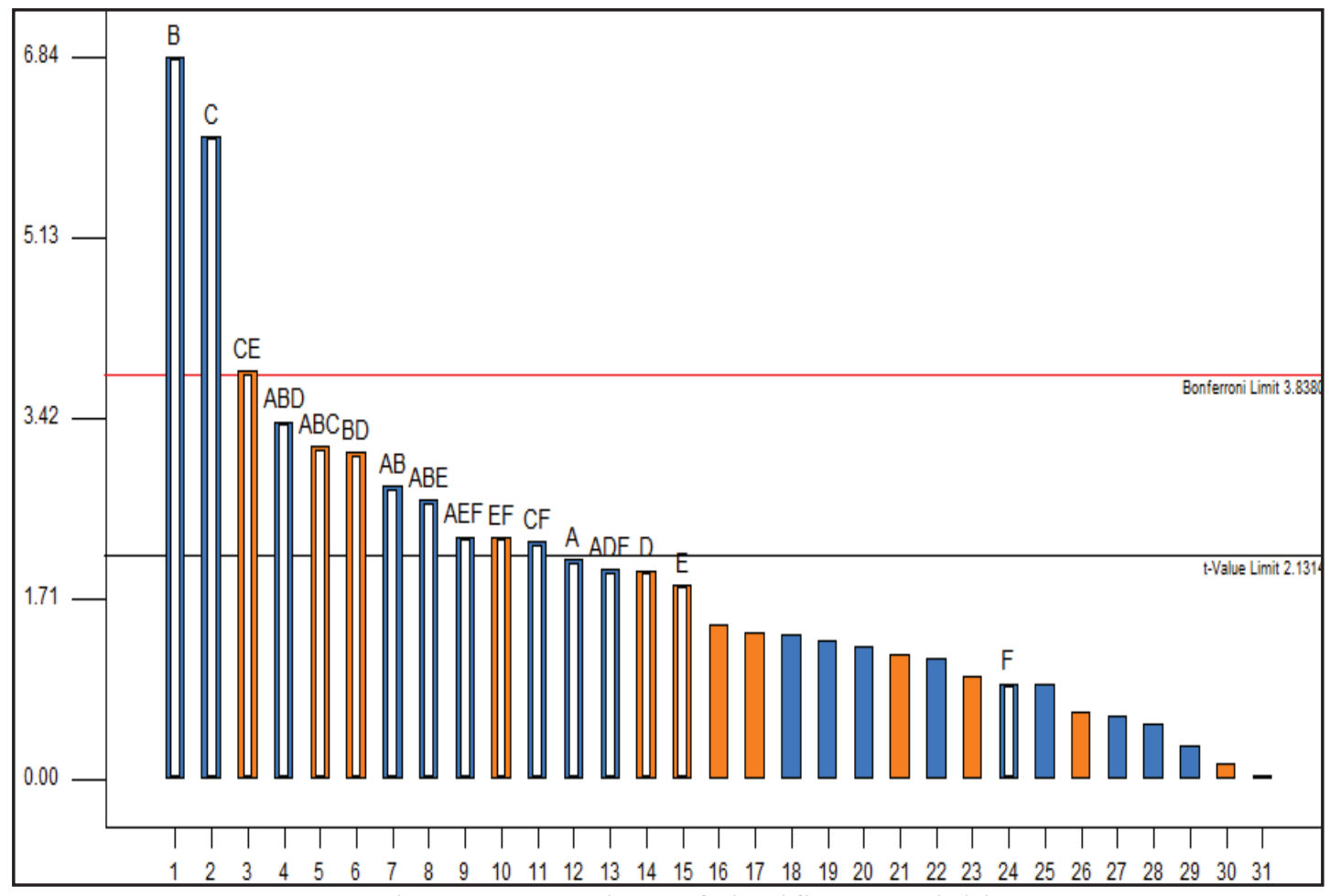

Fig. 3. Pareto chart of significant variables

The most significant factors were determined based on the analyzed results shown by the Pareto chart (Fig. 3). The factors that are above Bonferroni limit, factor B (peptone concentration), and $\mathrm{C}$ (temperature) are the most significant factors. The factors that are between Bonferroni and t-value limit line can be considered as significant too. Meanwhile, the parameters which are below the t-value limit line are insignificant factors and those variables can be ignored. The concentration of peptone and temperature enhanced L-asparaginase activity.

Table 2: Analysis of variance (ANOVA) for the screening of significant factors

\begin{tabular}{|c|c|c|c|c|c|}
\hline Sources & $\begin{array}{l}\text { Sum of } \\
\text { Squares }\end{array}$ & $\mathrm{df}$ & $\begin{array}{l}\text { Mean } \\
\text { Square }\end{array}$ & F Value & $\begin{array}{l}\text { p-value } \\
\text { Prob }>F\end{array}$ \\
\hline $\begin{array}{l}\text { Model } \\
\text { (significant) }\end{array}$ & 0.46 & 16 & 0.029 & 11.03 & $<0.0001$ \\
\hline A: Carbon & 0.011 & 1 & 0.011 & 4.36 & 0.0543 \\
\hline B: Nitrogen & 0.12 & 1 & 0.12 & 46.72 & $<0.0001$ \\
\hline $\begin{array}{l}\mathrm{C}: \\
\text { Temperature }\end{array}$ & 0.097 & 1 & 0.097 & 37.02 & $<0.0001$ \\
\hline $\mathrm{D}: \mathrm{pH}$ & 0.01 & 1 & 0.01 & 3.92 & 0.0664 \\
\hline $\begin{array}{l}\text { E: Agitation } \\
\text { speed }\end{array}$ & 8.91E-03 & 1 & 8.91E-03 & 3.4 & 0.0849 \\
\hline $\begin{array}{l}\text { F: Inoculum } \\
\text { sizes }\end{array}$ & $2.16 \mathrm{E}-03$ & 1 & $2.16 \mathrm{E}-03$ & 0.83 & 0.3776 \\
\hline $\mathrm{R}^{2}$ & 0.9217 & $\begin{array}{c}\text { Adjusted } \\
\mathrm{R}^{2}\end{array}$ & 0.8381 & $\begin{array}{c}\text { Predicted } \\
\mathrm{R}^{2}\end{array}$ & 0.6436 \\
\hline
\end{tabular}


Table 2 shows a summary of the ANOVA analysis. The F-value of the Model was 11.03 and its p-value was $<0.0001$ which was less than 0.05 implies the model was significant. All of the values of $p$-value or Prob $>F$ less than 0.05 indicate model terms are significant whereas the values greater than 0.1 indicate the model terms are not significant. The $p$-values were the indicator of the importance of each correlation among the tested variables [23]. As shown in the Pareto chart, factor B (peptone concentration; nitrogen source) and C (temperature) were important factors since the $\mathrm{p}$-value for that variable were less than 0.05 while the others were greater than 0.05 .

Table 3: Controllable factors and their coded levels for the Face Centered Composite Design (FCCD)

\begin{tabular}{lccc}
\hline Factor & Code & \multicolumn{2}{c}{ Variable levels } \\
& & $-1($ Low $)$ & $+1($ High $)$ \\
\hline Peptone $(\mathrm{g} / \mathrm{l})$ & $\mathrm{A}$ & 1.00 & 2.00 \\
Temperature $\left({ }^{\circ} \mathrm{C}\right)$ & $\mathrm{B}$ & 30 & 40 \\
\hline
\end{tabular}

In present work, Face Centered Composite Design (FCCD) from (RSM) was employed to optimize the effective parameters with a minimum number of trials. This method helps to analyze the interaction between the tested parameters. The two significant factors obtained from the previous experiment were optimized. The low $(-1)$ and high $(+1)$ levels of each variable were designated respectively as illustrated in Table 3. High and low levels of the substrate may lead to the fluctuation of the yield of the process [14]. As illustrated by them, the decreased L-asparaginase activity was due to the substrate inhibition when the substrate used in a high level. Meanwhile, when a low level of substrate is used, it may decrease the yield because of less nutrient availability for microbial growth and metabolite synthesis. $\mathrm{pH} 7$ was selected as previous studies revealed that the $\mathrm{pH}$ condition was the most suitable for the growth of any Bacillus sp.[24]. The same observation also found for the isolate Streptomyces ABR2 at this $\mathrm{pH}$ of 7.0 [25]. While inoculum size and agitation speed were fixed at $2 \%$ and $150 \mathrm{rpm}$ respectively. Both factors were insignificantly influenced to the culture, thus, the lowest level value was used in the optimization condition of the culture.

The complete experimental results are listed in Table 4.

Table 4: Experimental results of FCCD

\begin{tabular}{rccccc}
\hline Run & $\begin{array}{c}\text { Peptone } \\
(\mathrm{g} / \mathrm{L})\end{array}$ & $\begin{array}{c}\text { Temperature } \\
\left({ }^{\circ} \mathrm{C}\right)\end{array}$ & $\begin{array}{c}\text { L-asparaginase } \\
\text { activity }(\mathrm{U} / \mathrm{mL})\end{array}$ & $\begin{array}{c}\text { Protein } \\
\text { concentration } \\
(\mathrm{mg} / \mathrm{mL})\end{array}$ & $\begin{array}{c}\text { Specific } \\
\text { activity }(\mathrm{U} / \mathrm{mg})\end{array}$ \\
\hline 1 & 1.00 & 40.00 & $0.13 \pm 0.082$ & $0.02 \pm 0.012$ & 6.5 \\
2 & 1.50 & 35.00 & $0.16 \pm 0.129$ & $0.01 \pm 0.098$ & 16.0 \\
3 & 1.50 & 30.00 & $0.15 \pm 0.054$ & $0.02 \pm 0.120$ & 7.5 \\
4 & 1.50 & 40.00 & $0.16 \pm 0.100$ & $0.02 \pm 0.011$ & 8.0 \\
5 & 1.00 & 30.00 & $0.13 \pm 0.024$ & $0.01 \pm 0.044$ & 13.0 \\
6 & 1.00 & 35.00 & $0.13 \pm 0.071$ & $0.01 \pm 0.004$ & 13.0 \\
7 & 2.00 & 40.00 & $0.07 \pm 0.090$ & $0.01 \pm 0.011$ & 7.0 \\
8 & 1.50 & 35.00 & $0.17 \pm 0.110$ & $0.01 \pm 0.014$ & 17.0 \\
9 & 1.50 & 35.00 & $0.19 \pm 0.010$ & $0.01 \pm 0.068$ & 19.0 \\
10 & 2.00 & 30.00 & $0.11 \pm 0.017$ & $0.02 \pm 0.049$ & 5.5 \\
11 & 1.50 & 35.00 & $0.18 \pm 0.018$ & $0.01 \pm 0.113$ & 18.0 \\
12 & 2.00 & 35.00 & $0.06 \pm 0.032$ & $0.02 \pm 0.012$ & 3.0 \\
13 & 1.50 & 35.00 & $0.20 \pm 0.013$ & $0.01 \pm 0.002$ & 20.0 \\
\hline \hline
\end{tabular}


https://doi.org/10.31436/iiumej.v21i2.1351

Table 5: Analysis of variance (ANOVA) for optimization of response function

\begin{tabular}{|c|c|c|c|c|c|}
\hline Sources & $\begin{array}{l}\text { Sum of } \\
\text { Squares }\end{array}$ & $\mathrm{df}$ & $\begin{array}{l}\text { Mean } \\
\text { Square }\end{array}$ & F Value & $\begin{array}{l}\mathrm{p} \text {-value } \\
\text { Prob }>\mathrm{F}\end{array}$ \\
\hline $\begin{array}{l}\text { Model } \\
\text { (significant) }\end{array}$ & 0.021 & 3 & $6.860 \mathrm{E}-003$ & 22.02 & 0.0002 \\
\hline A: Peptone conc. & $3.758 \mathrm{E}-003$ & 1 & $3.758 \mathrm{E}-003$ & 12.07 & 0.0070 \\
\hline B: Temperature & $1.226 \mathrm{E}-004$ & 1 & $1.226 \mathrm{E}-004$ & 0.39 & 0.5460 \\
\hline $\mathrm{A}^{2}$ & 0.017 & 1 & 0.017 & 53.61 & $\begin{array}{c}< \\
0.0001\end{array}$ \\
\hline Residual & 2.803E-003 & 9 & $3.115 \mathrm{E}-004$ & & \\
\hline $\begin{array}{l}\text { Lack of Fit (not } \\
\text { significant) }\end{array}$ & $2.081 \mathrm{E}-003$ & 5 & $4.162 \mathrm{E}-004$ & 2.30 & 0.2194 \\
\hline C.V (\%) & 12.33 & & & & \\
\hline $\mathrm{R}^{2}$ & 0.8801 & $\begin{array}{l}\text { Adjusted } \\
\mathrm{R}^{2}\end{array}$ & 0.8402 & $\begin{array}{c}\text { Predicted } \\
\mathrm{R}^{2}\end{array}$ & 0.7228 \\
\hline
\end{tabular}

ANOVA for the quadratic model for optimization process parameters is shown in Table 5 . The Model F-value of 22.02 implies the model is significant. The values of the p-value less than 0.05 reflect that the model terms were significant. In this case, $\mathrm{A}$ and $\mathrm{A}^{2}$ were significant variables. Values more than 0.1000 show the model terms are not significant. The lack of fit of the model is not significant indicated that it was reasonable for the present work. The CV value is also considered as an important value since it determines the reproducibility of the model and helps to determine statistical reliability. The estimation is less accurate when the CV ratio is large. If the value is less than $15 \%$, the model reliability is good. In the present work, the CV value was 12.33 showing reliability and reproducibility of the model. The accuracy of the model developed can be determined by the $\mathrm{R}^{2}$, adjusted $\mathrm{R}^{2}$, and standard deviation values. $\mathrm{R}^{2}$ or known as the coefficient of determination is a number indicates how well data fit a statistical model. Generally, when the $\mathrm{R}^{2}$ value is closer to 1 , the linear regression fits the data is better. Based on Table 5, the $\mathrm{R}^{2}$ value for the model was 0.8801 . The predicted $\mathrm{R}^{2}$ of 0.7228 was in reasonable agreement with the adjusted $\mathrm{R}^{2}$ of 0.8402 . The value of the "Adeq Precision" obtained was 10.824 . This value measures the signal to noise ratio. The ratio of 10.824 indicated an adequate signal. Thus, the model could be used to navigate the design space.

A multiple regression analysis was used to relate the response of L-asparaginase activity (Y) with the two variables studied using a second-order polynomial. It can be represented by the following equation of (1) in terms of coded factors:

$\mathrm{Y}=-0.36398+0.81268 \mathrm{~A}-9.04033 \times 10^{-4} \mathrm{~B}-0.28758 \mathrm{~A}^{2}$

In Eq. (1), the coded factors A and B represent peptone concentration and temperature, respectively. A positive sign in front of the A-code represents good effect, while negative sign in front the B code can be deduced as a bad effect on the response function (Y). The positive value of the main effect denotes that higher activity of the enzyme would result in at a higher level of the factor whereas a factor with negative sign denotes that its lower level would provoke higher L-asparaginase activity. Previous studies confirmed that when the effect of a factor was positive, an increase in the value of the enzyme activity efficiency was observed [23]. Besides, a coefficient close to zero value means that the factor has little impact or no 
impact on the response. The A term of peptone concentration had the highest effect indicating that it was the most important component for L-asparaginase production. The linear term of peptone concentration $(A)$ has a higher effect value than the square term $\left(\mathrm{A}^{2}\right)$, indicating that the variable has more influence on enzyme production. It means that any alteration in the level could influence the production in a significant manner. Based on the above equation, the coefficient of B (temperature) is close to zero. Only peptone concentration influenced Lasparaginase activity produced by the strain positively.

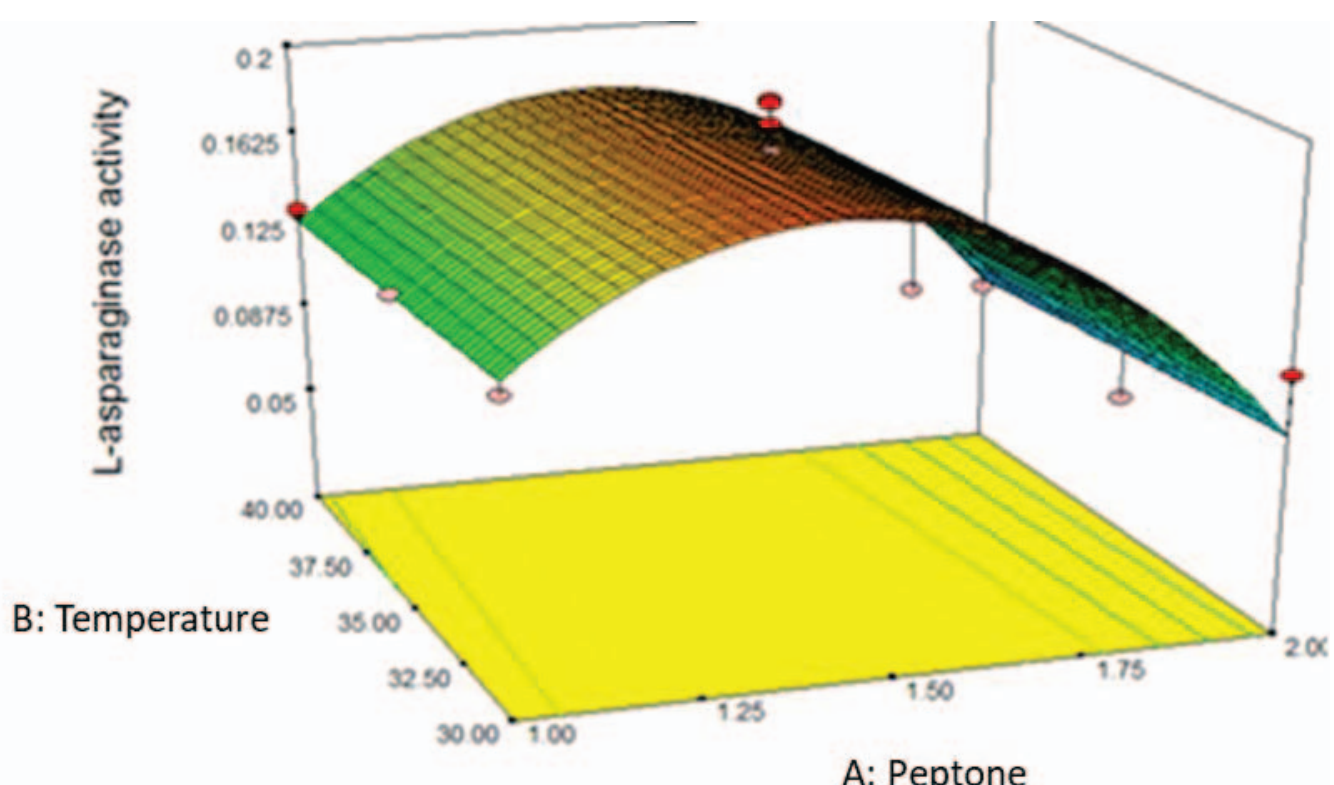

Fig. 4. A three-dimensional response surface plot showing the effect of peptone and temperature on the L-asparaginase activity.

The contour plot and Three-Dimensional (3D) graph are used to show the interaction between the involved variables. The curvature observed in a three-dimensional surface plot represents the prominent effect of peptone concentration on L-asparaginase activity (Fig. 4). The plot reveals that peptone concentration is proportional to the L-asparaginase activity. It seems like up to certain limits, the increased concentration of peptone will improve the enzyme activity. The activity of L-asparaginase was the highest at the middle level of peptone and lower level of temperature. The contour is slightly inclined towards temperature indicating that nitrogen source concentration; peptone was a slight influenced on temperature. Fig. 3 demonstrated that peptone at a concentration range of 1.40-1.50 g/l is optimum (middle level). The contour is elliptical indicating that both were independent of each other.

The predicted L-asparaginase activity for a particular set of operating culture conditions was numerically showed in the same Fig. 4. Based on the analysis of the contour plot, Lasparaginase activity increases to a maximum value with the increasing level of peptone to 1.40 $\mathrm{g} / \mathrm{L}$ where the temperature was at its lower level $\left(30^{\circ} \mathrm{C}\right)$. Further increment of the variables beyond the previously mentioned level shows an inhibitory effect on enzyme activity. 
https://doi.org/10.31436/iiumej.v21i2.1351

Table 6: Optimum-operating conditions for maximizing L-asparaginase

\begin{tabular}{ccccc}
\hline $\begin{array}{c}\text { Peptone } \\
\text { concentration } \\
(\mathrm{g} / \mathrm{L})\end{array}$ & $\begin{array}{c}\text { Temperature } \\
\left({ }^{\circ} \mathrm{C}\right)\end{array}$ & \multicolumn{2}{c}{$\begin{array}{c}\text { L-asparaginase activity } \\
(\mathrm{U} / \mathrm{mL})\end{array}$} & $\begin{array}{c}\text { Percentage } \\
\text { difference }(\%)\end{array}$ \\
1.41 & 30.00 & 0.183 & $0.19 \pm 0.03$ & 3.83 \\
\hline
\end{tabular}

Model validation was performed according to the condition generated by the software. The optimal values of parameters are as follows: peptone concentration $1.41 \mathrm{~g} / \mathrm{L}$ and temperature $30^{\circ} \mathrm{C}$, with corresponding L-asparaginase production at $0.183 \mathrm{U} / \mathrm{mL}$ (as shown in Table 6). The validation experiments were performed (triplicates) to find out the experimental results for enzyme activity. On conducting the experiments under these conditions, $0.19 \pm 0.03 \mathrm{U} / \mathrm{mL}$ of L-asparaginase activity was recorded. According to Saeed Gholamian and co-worker, the optimum temperature for growth of Bacillus sp. and L-asparaginase production was $37^{\circ} \mathrm{C}$ [24]. Deshpande and co-workers found that the addition of peptone into the medium growth favored maximum enzyme production by Streptomyces ginsengisoli [26]. Other studies reported that the presence of peptone enhanced the growth of Bacillus sp. because it increased the dry weight of the cell and shortened the lag period where the bacteria are adjusting to the new environment and [27]. While Farag and co-workers reported that L-asparagine was the best nitrogen source for the new fungal isolate, A. terreus [28]. The maximum growth of the bacterial strain and Lasparaginase activity were recorded at the temperature. The experimental results were compared to the predicted L-asparaginase activity and the percentage error was calculated. It found that the values given by the software were following by with the experimental values with a small percentage difference $(3.83 \%)$.

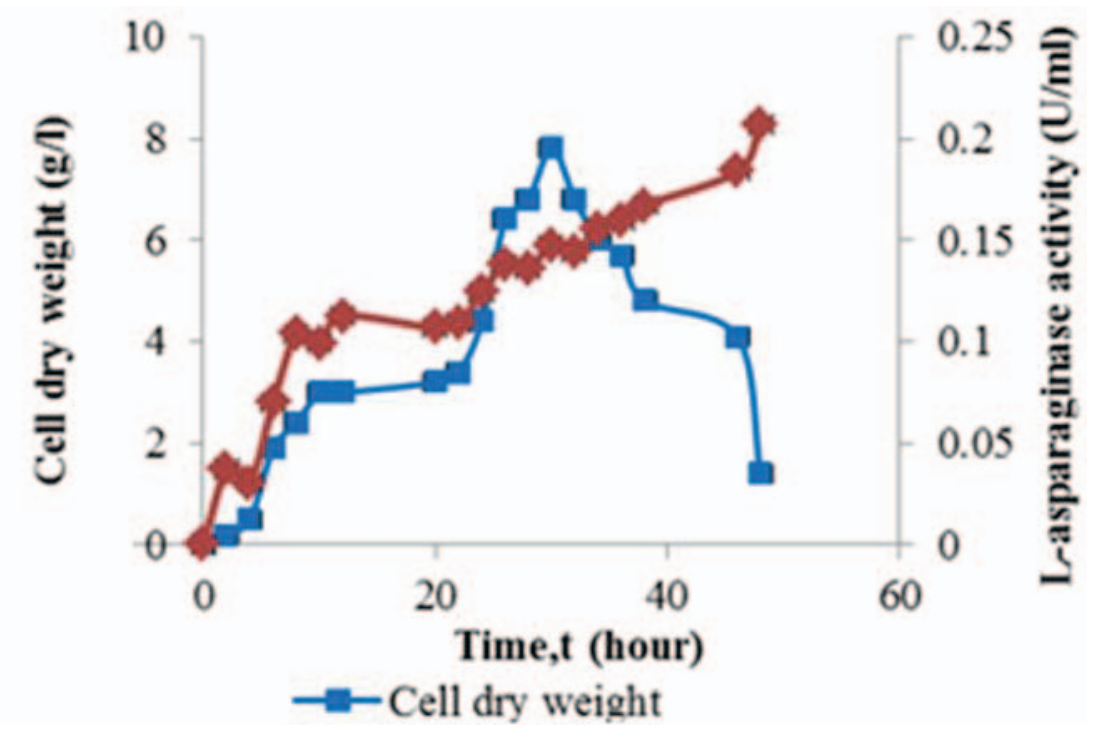

Fig. 5. A graph showing the correlation between cell dry weight (g/l) and L-asparaginase activity at different interval times.

The relationship between biomass concentration and L-asparaginase activity within 48 hours fermentation is shown the Fig. 5. The biomass concentration was increased gradually with the culture duration from 2 to 30 hours. At the 30th hour of incubation, it showed the maximum $(7.8 \mathrm{~g} / \mathrm{l})$ biomass production. The biomass concentration sharply declined beyond 30 hours toward 48 hours. In this study maximum, L-asparaginase metabolite production occurred at the 
end of the exponential growth phase. The L-asparaginase production declined to indicate its accumulation after a certain period of growth [29]. It found that the specific rates are high in the early part of the fermentation and later it declined steadily as the fermentation proceeds due to the disappearance of nutrients and the accumulation of toxic products.

\subsection{CONCLUSION}

Peptone concentration and temperature were the most influential parameters in stimulating L-asparaginase activity from Bacillus sp. The optimal conditions for L-asparaginase activity were at $30^{\circ} \mathrm{C}$ with $1.41 \mathrm{~g} / \mathrm{L}$ of peptone concentration. The L-asparaginase production under optimized conditions increased from $0.15 \pm 0.023 \mathrm{U} / \mathrm{mL}$ to $0.19 \pm 0.03 \mathrm{U} / \mathrm{mL}$. This study showed that the optimization of L-asparaginase production has been successfully achieved through Face Centred Composite Design (FCCD) of Response Surface Methodology (RSM).

\section{REFERENCES}

[1] Cachumba JJM, Antunes FAF, Peres GFD, Brumano LP, Santos JCD, Silva SSD. (2016) Curent applications and different approaches for microbial L-asparaginase production. Brazilian $\quad$ J https://doi.org/http?//dx.doi.org/10.1016/j.bjm.2016.10.004

[2] Kumar NSM, Shimray CA, Indrani D. (2014) Reduction of Acrylamide Formation in Sweet Bread with L -Asparaginase Treatment. Food Bioprocess Technol, 7:741-748. https://doi.org/10.1007/s11947-013-1108-6

[3] Amena S., Vishalakshi N., Prabhakar M., Dayanand A. LK. (2010) Production, purification and characterization of 1-asparaginase from treptomyces gulbargensis. Brazilian J Mocrpbiology, 41:173-178. https://doi.org/doi 10.1590/S1517838220100001000025

[4] Verma N, Kumar K, Kaur G, Anand S. (2007) L-asparaginase: A promising chemotherapeutic agent. Crit Rev Biotechnol, 27:45-62. https://doi.org/doi:10.1080/07388550601173926

[5] Jha, S K, PAsrija D., Sinha RK, Singh HR, Nigam VK VAS. (2012) Microbial Lasparaginase: A review on current scenario and future prospects. Int J Pharm Sci Res, 3:3076-3090. https://doi.org/http://dx.doi.org/10.13040/IJPSR.0975-8232.3(9).307690

[6] Zuo S, Zhang T, Jiang B, Mu W. (2014) Recent research progress on microbial 1asparaginases. Appl Microbiol Biotechnol, 99:1069-1079. https://doi.org/10.1007/s00253-014-6271-9

[7] Pieters R, Hunger SP, Boos J, Rizzari C, Silverman L, Baruchel A, Goekbuget N, Schrappe M, Pui C. (2011) L-Asparaginase Treatment in Acute Lymphoblastic Leukemia. Cancer, 117:238-249 . https://doi.org/10.1002/cncr.25489

[8] Jha SK, Pasrija D., Sinha RK, Singh HR, Nigam VK, Vidyarthi AS. (2012) Microbial L-asparaginse: A review on current scenario and future prospects. Int J Pharm Sci Res, 3:3076-3090

[9] Jain R, Zaidi KU, Verma Y, Saxena P. (2012) L-Asparaginase : A Promising Enzyme for Treatment of Acute Lymphoblastic Leukiemia. People's J Sci Res, 5:29-35

[10] Prakasham RS, Hymavathi M, Rao CS. (2010) Evaluation of Antineoplastic Activity of Extracellular Asparaginase Produced by Isolated Bacillus circulans. Appl Biochem Biotechnol, 160:72-80 . https://doi.org/10.1007/s12010-009-8679-8 
[11] Shibayama K, Takeuchi H, Wachino J ichi, Mori S, Arakawa Y. (2011) Biochemical and pathophysiological characterization of Helicobacter pylori asparaginase. Microbiol Immunol, 55:408-417. https://doi.org/10.1111/j.1348-0421.2011.00333.x

[12] Cappelletti D, Chiarelli LR, Pasquetto MV, Stivala S, Valentini G, Scotti C. (2008) Helicobacter pylorilasparaginase: A promising chemotherapeutic agent. Biochem Biophys Res Commun, 377:1222-226. https://doi.org/doi:10.1016/j.bbrc.2008.10.118

[13] Agarwal A, Kumar S, Veeranki VD, Kumar Æ. (2011) Effect of chemical and physical parameters on the production of L -asparaginase from a newly isolated Serratia marcescens SK-07. Letter in Applied Microbiology, 52:307-313. https://doi.org/10.1111/j.1472-765X.2011.03006.X

[14] Ghosh S, Murthy S, Govindasamy S, Chandrasekaran M. (2013) Optimization of Lasparaginase production by Serratia marcescens (NCIM 2919) under solid state fermentation using coconut oil cake. Sustainable Chemical Process, 1(9):1-8 . https://doi.org/DOI: 10.1186/2043-7129-1-9

[15] Eisele N, Linke D, Bitzer K, Na'amnieh S, Nimtz M, Berger RG. (2011) The first characterized asparaginase from a basidiomycete, Flammulina velutipes. Bioresour Technol, 102:3316-3321 . https://doi.org/10.1016/j.biortech.2010.10.098

[16] Lopes AM, Oliveira-Nascimento L de, Ribeiro A, Tairum CA, Breyer CA, Oliveira MA de, Monteiro G, Souza-Motta CM de, Magalhães P de O, Avendaño JGF, CavacoPaulo AM, Mazzola PG, Rangel-Yagui C de O, Sette LD, Converti A, Pessoa A. (2017) Therapeutic 1-asparaginase: upstream, downstream and beyond. Crit Rev Biotechnol, 37:82-99 . https://doi.org/10.3109/07388551.2015.1120705

[17] Jimat DN, Baizura I, Mohamed F, Azmi AS, Zainudin Z. (2015) Isolation and Characterization of Thermophilic Bacteria Producing L-Asparaginase from Malaysia Hotspring and Enzyme Activity Using Different Carbon and Nitrogen Sources. J Appl Sci Agric, 10:69-77

[18] Ahmad T, Danish M, Kale P, Geremew B, Adeloju SB, Nizami M, Ayoub M. (2019) Optimization of process variables for biodiesel production by transesterification of flaxseed oil and produced biodiesel characterizations. Renew Energy, 139:1272-1280. https://doi.org/10.1016/j.renene.2019.03.036

[19] Gulati R, Saxena RK, Gupta R. (1997) A rapid plate assay for screening L -asparaginase producing. Lett Appl Microbiol, 24:23-26

[20] Jimat DN, Mohamed IBF, Azmi AS, Jamal P. (2017) Purification and partial characterization of L- asparaginase enzyme produced by newly isolated Bacillus sp. IIUM Eng J, 18:1-10 https://doi.org/10.31436/iiumej.v18i2.654

[21] Bradford MM. (1976) A Rapid and Sensitive Method for the Quantitation Microgram Quantities of Protein Utilizing the Principle of Protein-Dye Binding. Anal Biochem, 72:248-254

[22] Hymavathi M, Sathish T, Brahmaiah P, Prakasham RS. (2010) Impact of Carbon and Nitrogen Sources on L-Asparaginase Production by Isolated Bacillus circulans (MTCC 8574 ): Application of Saturated Plackett-Burman Design. Chem Biochem Eng Q, 24:473-480

[23] Mungi H, Carvalho R, Ilegar S. (2014) Optimization of L-asparaginase production form Pseudomonas fluorescens by Response Surface Methodology. Int J Curr Microbiol Appl Sci, 3:350-362

[24] Gholamian, S.; Gholamian, S.;Nazemi, A.;Nargesi MM. (2013) Optimization of Culture Media for L Asparaginase Production by Newly Isolated Bacteria, Bacillus sp. GH5 1. Microbiology, 82:856-863 . https://doi.org/10.1134/S0026261714010032

[25] Sudhir AP, Dave BR, Trivedi KA, Subramanian RB. (2012) Production and 
amplification of an L-asparaginase gene from actinomycete isolate Streptomyces ABR2. Ann Microbiol, 62:1609-1614 . https://doi.org/10.1007/s13213-011-0417-0

[26] Deshpande N, Choubey P, Agashe M. (2014) Studies on Optimization of Growth Parameters for L-Asparaginase Production by Streptomyces ginsengisoli. The Scientific World Journal, :1-6 . https://doi.org/10.1155/2014/895167

[27] Fooladi J, Sajjadian A. (2010) Screening the thermophilic and hyperthermophilic bacterial population of three Iranian hot-springs to detect the thermostable $\alpha$-amylase producing strain. Iran J Microbiol, 2:49-53

[28] Farag AM, Hassan SW, Beltagy EA, El-Shenawy MA. (2015) Optimization of production of anti-tumor 1-asparaginase by free and immobilized marine Aspergillus terreus. Egypt J Aquat Res, 41:295-302 . https://doi.org/10.1016/j.ejar.2015.10.002

[29] Thaer, T.A. and Ellaiah P. (2013) L-Asparaginase production by a streptomycete and optimization of production parameters. J Pharm Biomed Sci, 29:859-869 